\title{
Epidemiologisk forskning om uførepensjon i Norden
}

\author{
Johan Håkon Bjørngaard ${ }^{1}$, Steinar Krokstad ${ }^{1}$, Roar Johnsen ${ }^{1}$, Anita Oxaas Karlsen ${ }^{1}$, \\ Kristine Pape ${ }^{1}$, Morten Støver ${ }^{1}$, Erik Sund ${ }^{2}$ og Steinar Westin ${ }^{1}$ \\ 1) Norges teknisk-naturvitenskapelige universitet, Institutt for samfunnsmedisin, 7489 Trondheim \\ 2) Norges teknisk-naturvitenskapelige universitet, Geografisk institutt, 7491 Trondheim \\ Korrespondanse: johan.h.bjorngaard@ntnu.no
}

\begin{abstract}
SAMMENDRAG
En relativ stor andel av befolkningen i yrkesaktiv alder i de nordiske landene mottar uførepensjon, og i Norge er det en klar tendens til økning. Parallelt med dette har interessen for forskning rundt uførepensjon som fenomen økt. Vi har i denne studien beskrevet den epidemiologiske forskningen om uførepensjon i Norden. I en systematisk litteraturgjennomgang fant vi 118 aktuelle artikler. Alle de nordiske landene er godt representert. Kohortstudier med uførepensjon som endepunkt utgjorde hovedvekten av materialet, hvor 67 var populasjonsbaserte mens 29 tok utgangspunkt i selekterte pasientpopulasjoner. I alt seks kohortstudier benyttet uførepensjon som eksponering. Vi fant videre syv kasus-kontrollstudier og ni forsøk. Det er betydelig dokumentasjon på at ulike sykdommer og helseplager er assosiert med økt risiko for uførhet, i tillegg til at sosioøkonomiske og arbeidsrelaterte forhold er av betydning. Gjennomgangen viser at den epidemiologiske forskningen for det meste har rettet blikket mot individuelle årsaker til uførepensjonering. Selv om denne forskningen er viktig, kan den neppe forklare økningen vi har sett i det siste tiåret. Den videre forskningen bør utforske nærmere hvordan individuell sårbarhet ender i utstøtelse fra arbeidslivet. Med tanke på den omfattende forskningen om årsaker på dette feltet, bør man også i større grad gjennomføre forsøk for å bedre utsatte gruppers arbeidsdeltakelse.
\end{abstract}

\section{Bjørngaard JH, Krokstad S, Johnsen R, Karlsen AO, Pape K, Støver M, Sund E, Westin S. Epidemiolo- gical research on disability benefits in the Nordic countries. Nor J Epidemiol 2009; 19 (2): 103-114.}

\section{ENGLISH SUMMARY}

A substantial part of the workforce in the Nordic countries receives a disability benefit, and in Norway this beneficiary rate is growing. As a result, disability benefit has been the subject of new interest and research. In this study we have reviewed the epidemiological research on disability benefit in the Nordic countries. A systematic review of the literature identified 118 articles of relevance. The majority of the articles are cohort studies using disability benefit as an end point, with 67 studies being population-based and 29 based on patient populations. Six cohort studies use disability benefit as an exposure. There were seven casecontrol studies and nine studies describing different interventions. In our material, associations between different health issues and work disability are well documented, as well as the importance of socioeconomic and work-related factors. The review reveals an emphasis on individual risk factors. Although important, individual factors alone can not explain the last decade's growth in the disability beneficiary rate. Further research should investigate more thoroughly how individual vulnerability results in work force exclusion. Given the extensive previous risk factor research, there is a need for interventions to improve vulnerable groups' work participation.

\section{INNLEDNING}

En relativ stor andel av befolkningen i yrkesaktiv alder i de nordiske landene mottar uførepensjon (1). Andelen er høyere enn i mange andre OECD-land (2). I følge OECD har utviklingen imidlertid vært noe forskjellig mellom de nordiske landene, hvor Norge og Sverige har økt sin andel, mens Finland har gått ned og Danmark har hatt stabilt nivå. I Norge var det ved slutten av 2008 i underkant av 340000 personer på uførepensjon - en økning på i underkant av 70000 fra 1999 (3). Selv om noe av denne økningen er knyttet til endringer i befolkningens alderssammensetning, har det også vært en betydelig økning i uførehyppighet justert for alder. Den relative økningen i andelen med uførepensjon har vært større for yngre aldersgrupper (figur 1). Denne utviklingen er imidlertid ikke unik for Norge (4). Veksten etter 2004 i Norge for de under 40 må også ses i sammenheng med ordningen med tidsbegrenset uførepensjon som trådte i kraft i 2004.

Uførepensjonen er en universell ordning i hele Norden, det vil si at den omfatter hele befolkningen, uten krav til økonomisk behovsprøving. Dette er et av de viktige kjennetegnene ved det vi litt upresist kaller den nordiske velferdsmodellen $(1,6,7)$. Forskning om uførepensjonering er avhengig av hvilket velferdssystem man har i de enkelte land. Det er lettere å sammenlikne resultater fra forskning innen de nordiske landene som 


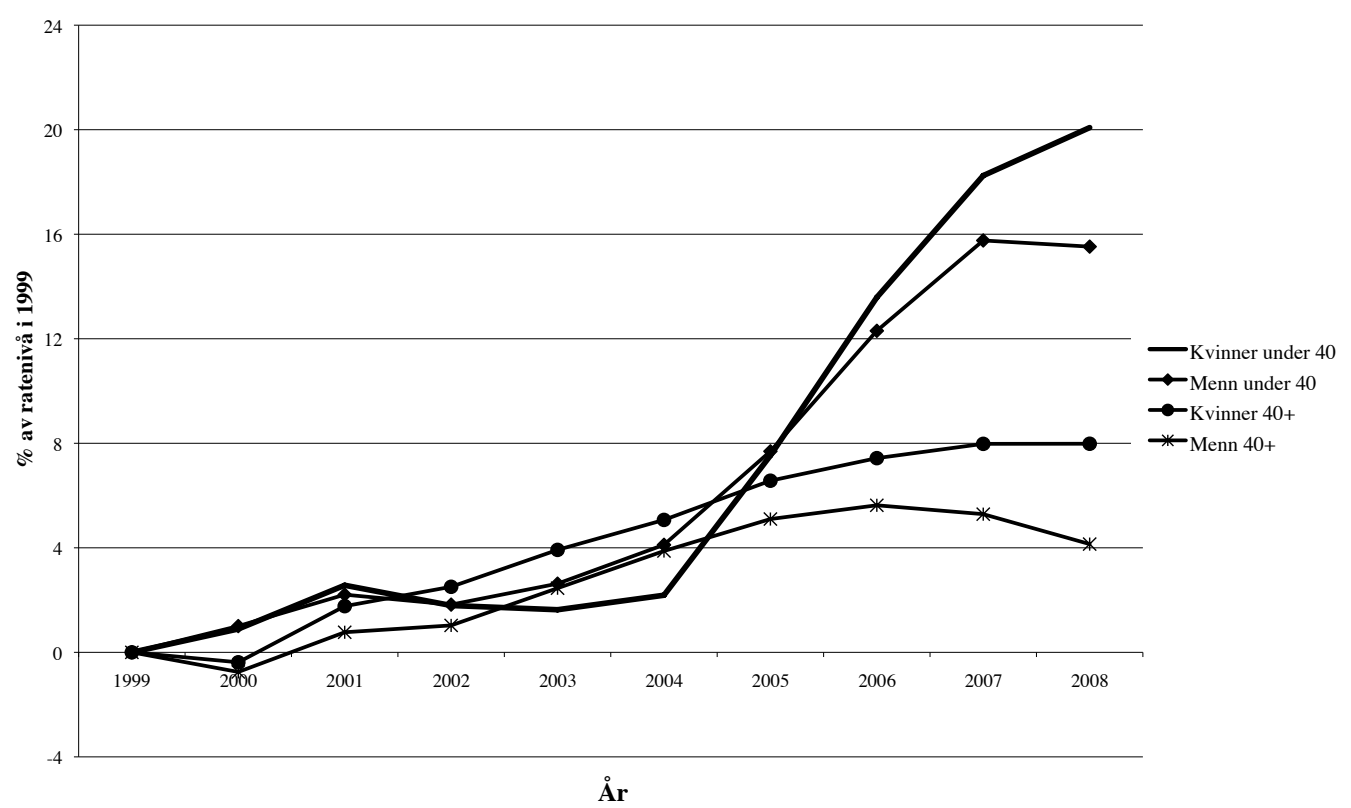

Figur 1. Antall uførepensjonerte per innbygger i perioden 1999 til 2008 i prosent av nivået i 1999. Kilde: $(3,5)$

har relativt like ordninger, enn med forskning $\mathrm{i}$ andre land med forskjellig velferdsordninger og trygdesystemer. De nordiske landene har også et annet fortrinn i gode trygderegistre - noe som legger forholdene til rette for forskning med uførepensjon som endepunkt.

Likevel er det grunn til å vurdere kritisk sammenligninger mellom de nordiske landenes uførestatistikk. Tilgangen til uførepensjon avhenger av kravene for innvilgelse av ytelsen, men også av hvorvidt det finnes andre ordninger for tidlig avgang fra arbeidslivet enn den som knytter seg til sykdom, skade eller lyte. Den danske "efterlønsordningen" kan for eksempel ha fanget opp en betydelig andel arbeidstakere med svekket ervervsmessig evne som også kan være medisinsk betinget funksjonssvekkelse. Før vi i 1988 fikk ordningen med avtalefestet pensjon for en begrenset del av arbeidsstyrken (AFP) i Norge, var uførepensjonen den eneste muligheten for inntektssikret avgang for pensjonsalder.

Forskning på uførepensjon har fått ny aktualitet, både på grunn av den beskrevne samfunnsutviklingen og tilgang på gode datamaterialer. Det har tidligere vært gjennomført systematiske litteraturstudier som omfatter uførepensjon både i Norge og Sverige. I Hansen (red) (8) tar forfatterne utgangspunkt i flere aspekt ved trygdeforskning og inkluderer uførepensjon, førtidspensjonering, attføring, rehabilitering, samt forvaltning av trygd. En svensk SBU-rapport (9) satte i hovedsak søkelyset på sykefravær. Disse rapportene var henholdsvis fra 1999 og 2003 og speiler derfor ikke nyere forskning. I en kunnskapsoppsummering om sykefraværsforskningen fra 2006 gjør Ose m.fl. (10) en gjennomgang av litteraturen som i hovedsak er avgrenset til sykefravær. I de siste årene er det publisert et betydelig antall epidemiologiske studier om uførepensjon, noe som gjør en ny kunnskapsoppdatering aktuell.

Målet med denne studien er å systematisk gjennom- gå publiserte trygdeepidemiologiske studier utført i Norden etter 1990 med vekt på metodisk design, materiale og forklaringsvariabler.

\section{Materiale OG Metode}

\section{Litteratursok og avgrensning}

Vi ønsket å inkludere alle epidemiologiske studier om uførepensjon i Norden publisert i perioden etter 1990. Det er visse begrepsmessige forskjeller, og uførepensjon er ikke et innarbeidet søkeord i de vanlige medisinske litteraturdatabasene. Etter en vurdering av søkestrategi, ble det søkt i databasene EMBASE og MEDLINE i mars 2009. Det ble først søkt med Meshtermen pensions(exp) i begge databasene. I EMBASE ble det i tillegg søkt med work disability(exp), siden dette var en egen kategori i denne databasen. I tillegg ble det søkt på følgende nøkkelord i begge databaser: disability benefit, disability benefits, disability pension og disability pensions. Resultatene fra disse studiene ble deretter avgrenset til studier i de nordiske landene i perioden etter 1990.

Epidemiologiske studier ble avgrenset til å omfatte kasus-kontrollstudier basert på insidente tilfeller, kohortstudier, samt intervensjonsstudier. Tverrsnittstudier ble utelatt fordi det i slike design er problemer knyttet til at eksponering og utfall er målt samtidig. Forskningsrapporter, redaksjonelle kommentarer og studier som beskriver generelle tiltak for å redusere uførepensjonering ble ekskludert da kvaliteten på disse ikke er kontrollert like godt som i studier med fagfellevurdering.

\section{Resultater}

Søkene i EMBASE og MEDLINE ga til sammen i alt 498 unike treff. De utvalgte studiene ble vurdert etter avgrensningskriteriene. Til slutt sto vi igjen med i alt 
Tabell 1. Oversikt over antall epidemiologiske studier på uførepensjon i Norden i perioden 1990 til 2009.

\begin{tabular}{|c|c|c|c|c|c|}
\hline \multirow[t]{3}{*}{ Land } & \multicolumn{3}{|c|}{ Kohortstudier } & \multirow[t]{3}{*}{ Kasus-kontroll } & \multirow[t]{3}{*}{ Intervensjonsstudier } \\
\hline & \multicolumn{2}{|c|}{ Uførepensjon som konsekvens } & \multirow{2}{*}{$\begin{array}{l}\text { Uførepensjon som } \\
\text { eksponering }\end{array}$} & & \\
\hline & Populasjonsbaserte & $\begin{array}{c}\text { Pasient/selektert } \\
\text { materiale }\end{array}$ & & & \\
\hline Norge & 20 & 7 & 3 & & 2 \\
\hline Sverige & 17 & 10 & 2 & 7 & 2 \\
\hline Danmark & 12 & 4 & 1 & & \\
\hline \multirow[t]{2}{*}{ Finland } & 18 & 8 & & & 5 \\
\hline & Appendiks 1-A og B & Appendiks 2 & Appendiks 3 & Appendiks 4 & Appendiks 5 \\
\hline
\end{tabular}

118 studier som tilfredsstilte utvalgskriteriene, 69 av disse var fra 2004 eller senere.

Tabell 1 gir en oversikt over hvordan de 118 studiene fordelte seg på kategorier etter studiemetode og utvalg. Referansene til de ulike studiene er lagt i Appendiks 1-5. Flertallet av kohortstudiene analyserte uførepensjon som utfall, mens seks studier analyserte uførepensjonering som en eksponering. Det var i alt syv kasus-kontrollstudier og ni intervensjonsstudier.

\section{Populasjonsbaserte kohortstudier}

I alt 67 studier ble kategorisert som kohortstudier med formål å identifisere risikofaktorer for uførepensjon $\mathrm{i}$ populasjonen (Tabell 1 og Appendiks 1-A og B). En nærmere gjennomgang av disse viste at 50 studier undersøkte faktorer for generell uførepensjonering (se appendiks 1-A). Én av studiene var en delvis overlappende norsk versjon av en internasjonal publikasjon $(11,12)$. I alt syv tok utgangspunkt i uførepensjonering for spesielle diagnosegrupper og ni studier viste ikkejusterte resultater i tabellform (se appendiks 1-B). I tabell 2 har vi rapportert hvilke typer faktorer som ble undersøkt i de 50 studiene vist $\mathrm{i}$ appendiks $1-\mathrm{A}$, det vil si de studiene som undersøkte faktorer for generell uførepensjonering og som har rapportert justerte sammenhenger i tabellform. For å avgrense, men samtidig å eksemplifisere resultatene, har vi valgt å referere til konkrete artikler og ikke alle.

\section{Demografi og sosioøkonomisk status}

Tabell 2 viser at av 28 indikatorer på demografi (for eksempel kjønn, alder, sivilstand) viste 23 en stastistisk signifikant $(\mathrm{p}<.05)$ sammenheng, mens 30 av 33 indikatorer for sosioøkonomisk status viste en tilsvarende sammenheng. En svensk undersøkelse finner at kvinner og menn $\mathrm{i}$ aldersgruppen 55-64 år har henholdsvis omtrent 15 og 30 ganger høyere risiko for uførepensjon sammenlignet med aldersgruppen 16-24 år. Kvinner har opp mot to ganger så høy risiko som menn, men dette er aldersavhengig, og for de eldste er forholdet reversert (13). En norsk undersøkelse finner små, men signifikante forskjeller i uførepensjonering mellom ulike alderskohorter og ut ifra hvilken tidsperiode det ble søkt om uførepensjon (14). Flere studier benytter stratifiserte analyser på kjønn og aldersgrupper.
Tabell 2. Antall studier som har rapportert justerte ${ }^{1}$ sammenhenger mellom risikofaktorer og uførepensjon.

\begin{tabular}{lcc}
\hline Variabler & Antall assosiasjoner & Antall $\mathrm{p}<.05$ \\
\hline Demografi & 28 & 23 \\
Sosioøkonomisk status & 33 & 30 \\
Livsstil & 20 & 13 \\
Helse & & \\
$\quad$ - Overvekt & 14 & 10 \\
- Selvopplevd helse & 7 & 7 \\
- Somatisk helse & 34 & 31 \\
- Psykisk helse & 22 & 21 \\
- Fysisk form & 9 & 8 \\
Geografiske forhold & 3 & 2 \\
Arbeidsforhold & & \\
- Arbeidstid (deltid, skiftarbeid) & 6 & 4 \\
- Fysisk belastning & 9 & 8 \\
- Psykososialt arbeidsmiljø & 18 & 11 \\
- Organisasjonsfaktorer & 4 & 2 \\
Annet & 13 & 10 \\
\hline
\end{tabular}

${ }^{1}$ Her er det tatt utgangspunkt $\mathrm{i}$ de mest fullstendige justeringene $\mathrm{i}$ hver av studiene, minst aldersjusterte sammenhenger.

Psykososiale forhold i privatlivet, både det å være enslig, ugift og separert/skilt, gir noe økt risiko for uførepensjonering. Det å bli tenåringsmor har også i én studie vist seg å øke risikoen for uførepensjonering (15).

Utdanning og yrkesklasser er noe ulikt klassifisert $\mathrm{i}$ forskjellige studier. Dette gjør sammenligninger vanskelige. Omtrent like mange benytter sosial klasse (yrkesklasse) og utdanning som mål på sosioøkonomisk status, mens det er få studier som benytter inntekt. Majoriteten av studiene som har sett på betydningen av sosial klasse, finner to til tre ganger høyere risiko for uførepensjon ved å tilhøre den laveste sammenliknet med den høyeste klassen. Resultatene viser tilsvarende forhold for utdanning. Yrkesklasse synes å ha størst betydning for menn, mens forskjeller i utdanning har størst betydning for kvinner. En norsk undersøkelse finner i tillegg også markante aldersforskjeller, hvor de sosioøkonomiske forholdene utgjør en mindre effekt $\mathrm{i}$ gruppen over 50 år, og da særlig for kvinner (12). Samtidig viser studier at betydningen av foreldrenes sosioøkonomiske status på risiko for uførepensjon for unge voksne er beskjeden $(16,17)$. 


\section{Livsstil}

Flere studier har vist at risiko for uførepensjonering er assosiert med faktorer knyttet til livsstil, for eksempel røyking, alkoholbruk og kriminell atferd. $\mathrm{Ni}$ av elleve undersøkte assosiasjoner mellom røyking og uførepensjon er statistisk signifikante, mens tilsvarende to av fire assosiasjoner for egenrapportert alkoholkonsum. Ellers har studier vist at kriminalitet, rusmisbruk og befatning med politi og barnevern øker risikoen for uførepensjonering (se for eksempel Upmark m.fl. (18)). Fem av seks assosiasjoner mellom fysisk aktivitet og risiko for uførepensjon viser at det å være fysisk aktiv på fritiden reduserer risikoen.

\section{Helse}

En lang rekke subjektive og objektive helseforhold er analysert som risikofaktorer for uførepensjonering. For de aller fleste $(90 \%)$ finner man en sammenheng med trygding. Dette gjelder for relativt objektive mål på helse, for eksempel høyt blodtrykk, for tidlig fødsel, kreft, lavt oksygenopptak og overvekt. I tillegg er det en omfattende litteratur som viser at selvopplevd dårlig helse - både psykisk og fysisk - er sterkt assosiert med forhøyet risiko for uførepensjonering.

Flere studier har i lys av vektendringer i befolkningen satt søkelys på kroppsmasseindeks (KMI). Tendensen i undersøkelsene viser at særlig overvektige med KMI på 30 eller mer har forhøyet risiko for uførepensjonering. Der hvor det er studier som har sammenliknbar kategorisering, har fete (KMI>30) en relativ risiko sammenliknet med normalvektige ( $\approx$ KMI 20-25) som varierer betydelig mellom studier. For eksempel viser en svensk studie at unge menn med KMI på 30 eller mer har om lag $40 \%$ høyere risiko for uførepensjonering sammenliknet med normalvektige (19), mens en finsk befolkningsstudie viser relativ risiko på 7,4 for menn i alderen 20-34 år ved baseline (20). Det må imidlertid legges til at konfidensintervallene på disse estimatene er vide.

I alt 21 av 22 undersøkte assosiasjoner mellom psykisk helse og uførepensjon har vist en statistisk signifikant sammenheng. Depresjon har i flere studier vist seg å være en selvstendig risikofaktor. Det samme gjelder søvnproblemer, angst, mangel på sosial støtte og lav emosjonell kontroll. Høyere symptomtrykk angitt ved mer generelle selvrapporterte skalaer på psykiske plager har også vist forhøyet uførhetsrisiko. En norsk studie viste at depresjon og angst også økte risikoen for uførepensjonering for andre grunner enn psykiske lidelser (21). Videre har mer generelle spørsmål om tilfredshet med livet, subjektiv velvære og følelse av sammenheng i livet (sense of coherence) vist seg å være assosiert med uførepensjonering - også etter justering for en lang rekke mer objektive helsemål.

\section{Geografiske forhold}

Få studier har sett på geografiske forholds betydning for uførepensjon. I to av tre tilfeller hvor dette er analysert er det funnet en statistisk signifikant assosiasjon til uførepensjonering med utgangspunkt i geografiske variabler. En norsk studie viste at til tross for at de geografiske forskjellene i uføreandeler mellom kommuner var marginal, var det en viss forhøyet risiko for trygding i depriverte kommuner (22).

\section{Arbeidsforhold}

En dansk undersøkelse fant betydelige forskjeller i uførepensjonering mellom ansatte i ulike bransjer (23). To studier har undersøkt heltids- versus deltidsarbeid $i$ selekterte grupper, men resultatene $\mathrm{i}$ de to undersøkelsene spriker. En av tre studier finner økt risiko for uførepensjonering ved skiftarbeid for kvinner. To av tre danske studier finner økt risiko ved ansettelse $\mathrm{i}$ offentlig sektor, den ene kun for kvinner - den andre for begge kjønn og mest uttalt for menn.

Tabell 2 viser at fysisk belastende arbeid er signifikant assosiert med uførepensjon (åtte av ni assosiasjoner). Flere studier har sett på betydningen av ulike typer fysisk belastning, og hyppigst beskrevet er økt risiko ved egenrapportert stor belastning på overekstremitetene. En studie som ser på fysisk belastning som risikofaktor for uførepensjon med ulike diagnoser finner størst risiko for uførepensjonering med diagnose $i$ muskel- og skjelettsystemet, deretter sirkulasjonssystemet, mens risikoen ikke er økt for trygding med psykiatrisk diagnose (24).

Tabell 2 viser at i elleve av 18 assosiasjoner er psykososiale belastninger knyttet til arbeidet signifikante prediktorer for uførepensjon. Fire studier beskriver noe økt risiko for uførepensjon ved selvrapportert lite kontroll/medbestemmelse i arbeidssituasjonen. En finsk undersøkelse fant at kommunalt ansatte som jobbet på steder hvor det hadde foregått nedskjæringer hadde økt risiko for uførepensjon - RR henholdsvis 1,46 og 1,81 for mindre og større nedskjæringer (25).

\section{Kohortstudier med utgangspunkt $i$ pasientpopulasjoner}

I alt 29 kohortstudier tar for seg ulike pasientgrupper. Elleve av disse benytter uførepensjon som endepunkt for å si noe om prognose for den aktuelle pasientgruppen eller for å vurdere effekt av ulike behandlingsstrategier. Majoriteten av de 18 resterende artiklene tar utgangspunkt i ulike grupper med sykmeldte, og ser på relasjonen mellom sykefravær og uførepensjon. I en stor dansk kohort viser man at risikoen for uførepensjon i perioden 2001-2004 steg nærmest lineært med antall sykefraværsdager i 1998, og at stigningen var klart større i de yngste (under 40 år) enn blant de eldre (over 40 år) (26).

Studier som omfatter populasjoner med langtidssykmeldte viser blant annet at sosioøkonomisk status, omsorg for barn, diagnose og statsborgerskap har betydning for uførepensjonering. Langtidssykmeldte kvinner i deltidsjobb har større risiko for senere uførepensjon enn de som jobber fullt. Menn som er sykmeldt med en psykiatrisk diagnose har økt risiko både sammenlignet med kvinner med psykiatrisk diagnose og andre sykmeldte menn $(27,28)$. En ny undersøkelse som omfatter alle sykmeldte med psykiatrisk diagnose i Norge 
i 1997, viser at egenskaper ved kommuner (deprivasjon) er svakt assosiert med risiko for uførepensjon for kvinner (29).

\section{Kohortstudier med uforepensjon som eksponering}

I alt seks studier har analysert uførepensjonering som en eksponering, hvorav fem omhandlet dødeligheten blant uførepensjonerte sammenliknet med normalbefolkningen. Disse studiene viser gjennomgående en forhøyet mortalitetsrisiko for uførepensjonerte. For eksempel viste en norsk studie at justert relativ mortalitetsrisiko var omtrent den dobbelte for uførepensjonerte sammenliknet med dem som ikke var uførepensjonerte ved starten av oppfølging (30), og en svensk studie fant høyere mortalitet for uførepensjonerte, både for kvinner og menn og for ulike aldersgrupper (31).

\section{Kasus-kontrollstudier}

Vi fant syv kasus-kontrollstudier, alle svenske. Én studie undersøkte faktorer som var assosiert med å benytte såkalt hvilende uførepensjon (det vil si forsøke seg $\mathrm{i}$ arbeid uten at de risikerer å miste uførepensjonen) blant uførepensjonerte med muskel- og skjelettdiagnoser (32), og konkluderte med at det kan være hensiktsmessig å fortsette innsats for tilbakevending til arbeid også etter at uførepensjon er innvilget. To studier tok utgangspunkt i personer som hadde søkt om uførepensjon, hvor de som ikke fikk innvilget uførepensjon (kasus) ble sammenlignet med dem som fikk (kontroller) $(33,34)$. Forfatterne konkluderte med at det ikke var særlige forskjeller i diagnose mellom de som fikk og ikke fikk innvilget uførepensjon, og at helserelatert livskvalitet var dårligere for dem som ikke hadde fått innvilget trygd. To studier så på faktorer assosiert med livskvalitet og helse og helsetjenestebruk blant unge uførepensjonerte sammenliknet med en kontrollgruppe $(35,36)$. Her ble det blant annet konkludert med at eldre kvinnelige arbeidstakere rapporterte en bedring i selvopplevd helse etter uførepensjonstidspunktet. En studie fant indikasjoner på at arbeidsrelaterte faktorer var av betydning for uførepensjonering blant sykepleiere i hjemmetjenesten (37). Den siste studien fant at personer med førstegangs slag hadde høyere langtids sykefravær og var oftere uførepensjonert forut for slaget enn kontrollgruppen (38).

\section{Intervensjonsstudier}

Av intervensjonsstudiene inneholdt to, en norsk (39) og en svensk (40), tiltak rettet mot den generelle befolkningen. Den norske fant at systematisk oppfølging basert på utvidet sykmelding ikke reduserte uførepensjonering, mens den svenske fant ingen effekt på uførepensjonering av generelle arbeidsplasstiltak. De to arbeidsplassene som inngikk i studien hadde store forskjeller i den økonomiske innsatsen uten at det kunne måles noe effekt på avgangen i arbeidsstokken. De øvrige var rehabiliterings/behandlingstiltak rettet mot ulike grupper med muskel- og skjelettplager. Gjennomgående finnes det redusert uførepensjonering som følge av intensive behandlingstiltak som trening, medikamentell behandling og kognitiv trening, mens generelle rehabiliteringstiltak synes uvirksomme.

\section{DISKUSJON}

Vi har i denne studien beskrevet den epidemiologiske forskningen om uførepensjon i Norden med bakgrunn i en systematisk gjennomgang av litteraturen. Når vi summerer opp, er det gjort en lang rekke epidemiologiske studier i Norden med ervervsmessig uførhet som problemområde. Hovedvekten av litteraturen kan defineres som populasjonsbaserte kohortstudier. En betydelig del av litteraturen dreier seg om hvordan sykdom og helseplager er assosiert med risiko for uførhet. Det er også betydelig dokumentasjon på at sosioøkonomiske forhold er av stor betydning for uførepensjonering.

\section{Begrensninger ved denne studien}

Vår strategi for å velge ut litteratur kan ha vært sårbar for valg av framgangsmåte. For det første har vi utelatt forskning fra fagområder som ikke er registrert i de kliniske litteraturdatabasene MEDLINE og EMBASE. Videre har vi gjennomført en avgrensing knyttet til metodevalg. Det er ikke gjort annen kvalitetsvurdering av studiene enn den som ligger i vårt utvalg av design og valg av kun fagfellevurderte arbeider. Det er også mulig at de søkeordene vi har valgt ikke har fått med alle relevante studier. Vårt valg har vært knyttet særskilt til den epidemiologiske forskningen, uten at vi av den grunn underkjenner andre forskningsbidrag. Vi har gjennomgått et betydelig antall studier, noe som gjør det sannsynlig at vi har fått fram hovedtrekk ved denne litteraturen.

Studiene vi har gjennomgått er ofte vanskelig å sammenlikne. Det kan for eksempel være svært forskjellige tema som omhandles, eller at det ikke er anvendt samme måleinstrumenter eller lik kategorisering. Sammenliknbarheten er også vanskelig fordi kohortene er forskjellig sammensatt. For eksempel i de populasjonsbaserte kohortstudiene som tar for seg forhold ved arbeid eller arbeidsmiljø, er det store forskjeller mellom studiene, både når det gjelder sammensetningen av kohortene og hvilke forhold som er undersøkt. Det er videre viktig å understreke at antall statistisk signifikante assosiasjoner i litteraturen ikke nødvendigvis er uttrykk for viktigheten av disse funnene. Vår gjennomgang har i hovedsak vært beskrivende. En mer kritisk vurdering av litteraturen med henblikk på kvalitet og betydningen av funn ville krevd en annen tilnærmingsmåte.

\section{Forskningen er preget av sokelys på individuelle årsaker}

Epidemiologisk metode, og spesielt kohortstudier, er velegnete design når man skal identifisere årsaksforhold. Men når randomisering ikke er mulig, er det alltid vanskelig å vurdere om det er andre forhold enn de man har kontroll over i studiene som har spilt en rolle, 
såkalt konfundering. Videre ligger det en begrensning $\mathrm{i}$ at forskere innen dagens epidemiologi ofte er opptatt av individuelle egenskaper og atferd, og gjerne faktorer som lar seg kvantifisere. De epidemiologiske studiene kan derfor ha en tendens til å undervurdere betydningen av samfunnsforhold og rammefaktorer. Bakteppet, klimaet $\mathrm{i}$ arbeidslivet, normene i samfunnet, den løpende offentlige debatt som styrer meninger og holdninger, er vanskelig å fange. Slike samfunnsmessige forhold, som påvirker alle, arbeidsfolk, deres familie og venner, trygdefunksjonærer, leger, ledere og politikere, kan ha stor betydning for omfanget av sykmeldinger og uførepensjoner. For eksempel kan ideologiske endringer, endringer i bedriftenes rammevilkår, økonomiske eller politiske endringer ha stor betydning for virksomhetenes vilje og mulighet til å beholde arbeidstakere, selv om de ikke er av de mest effektive. Slike endringer kan trolig ha en betydningsfull effekt på utstøting av personer med sosiale og helsemessige problemer. Årsaksfaktorer på dette nivået vil vanligvis ikke bli avdekket i epidemiologiske studier basert på egenskaper ved individer.

\section{Sykdommer og skader som skaper uforhet}

Litteraturgjennomgangen viser at nesten alle undersøkte mål på sykdom og uhelse, og problemer allerede i fosterlivet, har betydning for uførerisiko. Spørsmålet er da om endringer $\mathrm{i}$ helse kan forklare økningen $\mathrm{i}$ tilgangen til uførepensjon. I dag er det psykiske sykdommer og muskel- og skjelettlidelser som dominerer uførestatistikken. Det er også beskrevet viktige bakenforliggende psykiatriske problemer ved uførepensjonering for somatiske lidelser (21). Om det er en reell økning i psykisk sykelighet i befolkningen som årsak til endringer i uførepensjonering er vanskelig å bedømme. Grensen mellom psykisk sykdom og mental helse er flytende. Endring i diagnostisk praksis, endring i oppmerksomhet omkring psykiske plager både i befolkingen og $\mathrm{i}$ helsetjenesten, mer åpenhet $\mathrm{i}$ befolkningen, endringer i legesøkningsatferd og så videre, kan ha betydning. Uansett vil det være et samspill mellom folks helseressurser og de krav som stilles $\mathrm{i}$ arbeidslivet som vil avgjøre den ervervsmessige evnen (41).

På generelt grunnlag er det imidlertid ingen holdepunkter for at nordmenns helse har blitt særlig svekket i løpet av de siste tiårene. Verken dødelighetsutviklingen eller data fra Helse-og levekårsundersøkelsene, som viser at om lag åtte av ti nordmenn vurderte helsen si som god eller meget god i 1985-2005, gir belegg for en slik hypotese (42). Vi må derfor anta at det er andre årsaker enn kun sykdom, skade eller lyte som forklarer endringer tilgangen til uførepensjon - til tross for at lovgivningen er basert på medisinske kriterier.

\section{Arbeidsrelaterte årsaker til uforepensjon}

Litteraturgjennomgangen viser at arbeidsplassrelaterte psykososiale, organisatoriske og fysiske forhold er assosiert med risikoen for uførhet, se for eksempel
Albertsen m.fl. og Stattin m.fl. $(43,44)$. Det er liten tvil om at forholdene $\mathrm{i}$ arbeidslivet fortsatt er viktige, selv om tidligere tiders grovt helseskadelige arbeidsforhold er sanert bort. Spørsmålet er om psykososiale helseskadelige forhold har fått større betydning i takt med endringer i arbeidslivet som hovedårsak til arbeidsplassrelatert ervervsmessig uførhet. På den andre siden er det fortsatt betydelige fysiske belastninger $\mathrm{i}$ for eksempel pleie- og omsorgsyrkene.

To norske studier viser at bosted også kan ha betydning for risikoen for å falle ut fra arbeidslivet $(22,29)$. I kommuner med hjørnesteinsbedrifter i konkurranseutsatte næringer kan mange utsettes for arbeidsledighet. Hvis utsiktene til nytt erverv er små og økonomien dårlig kan en stressende situasjon føre til at kroniske plager bli dominerende. Hvis kravene som stilles for å kunne skaffe seg en ny jobb er høye, kan ervervsmessig uførhet bli resultatet. Westin påpekte det relasjonelle forholdet mellom arbeidslivets krav og individets helseressurser, og viste at arbeidsløshet som følge av bedriftsnedleggelser kan medføre en betydelig økt risiko for uførepensjonering (45). En finsk studie i vår litteraturgjennomgang viste at risiko for uførepensjonering økte etter nedbemanning (25), et resultat som også er vist på andre forskningsfelt $(46,47)$. Dette kan igjen ha konsekvenser ut over den enkelte. Rege m.fl. (48) har for eksempel vist at risikoen for å bli uførepensjonert øker både som følge av nedleggelser eller nedbemanninger, og dersom mange i omgangskretsen blir trygdet.

\section{Sosiookonomiske forskjeller}

Det er en systematisk opphopning av mer negative årsaksforhold jo lavere man kommer på den sosiale rangstigen, se for eksempel Krokstad m.fl. (12). Selv i velferdsstater med universelle trygdeordninger har sosiale forskjeller vist seg å være vanskelig å redusere. Økende sosiale forskjeller i for eksempel lønninger, kan underminere den sosiale kontrakten. Det er god grunn til å følge utviklingen i den sosioøkonomiske trygdegradienten, og berettiget å stille spørsmål om det ligger et forebyggende potensial i utjevning av sosiale forhold.

\section{Kjonnsforskjeller}

Kvinner har i dag høyere risiko for uføretrygding enn menn, i alle fall blant yngre voksne. Tidligere var det flere menn enn kvinner som ble trygdet, men et krysningspunkt kom i 1980-årene i Norge (49). Hovedårsaken var at kvinner i økende grad entret arbeidsmarkedet, men det har i tillegg vist seg at kvinner systematisk har en høyere uførerisiko. Dette kan ha sammenheng med at mange kvinner faktisk har fysisk belastende arbeid og at belønningen oppleves som dårlig, spesielt i offentlig helse- og omsorgssektor (43). Trolig opplever kvinner i tillegg en sterkere rollekonflikt mellom ansvar for hjem og jobb, og de tar ofte hovedansvar for barn. Med andre ord er det grunn til å opprettholde at kjønnsperspektivet i trygdeforskningen er viktig. 


\section{Utfordringer videre}

Nyere studier viser at det fortsatt kan påvises overraskende individuelle årsaksforhold for trygding. Et eksempel på dette er påvisning av betydningen av søvnvansker, selv om søvnvansker er fraværende i trygdestatistikken (50). Det er med andre ord fortsatt viktig at den epidemiologiske forskningen befatter seg med individuelle årsaksforhold for trygding. Imidlertid mangler det studier som setter individuelle årsaksforhold inn i en kontekstuell ramme. En finsk tvillingstudie viser bare moderate genetiske bidrag til forskjeller $\mathrm{i}$ trygderisiko, men at det genetiske bidraget var større i yngre aldersgrupper (51). Dette indikerer at miljøfaktorer er svært viktige. Det er da særlig viktig å undersøke nærmere hvorvidt sykdom og uhelse er hovedårsak til reduksjonen av ervervsevnen, eller om det er endringer i personens omgivelser og arbeidsbetingelser som støter vedkommende ut. Det er også verdt å merke seg at få studier i vår gjennomgang har sett på trygdesystemet som aktør. Spørsmål som omhandler lovgivning og hvordan hjelpeapparatet fungerer bør også undersøkes nærmere.

Et annet viktig spørsmål i den epidemiologiske forskningen er å kunne beskrive når prosessen mot uførepensjon egentlig starter. Tilstander som vi har mindre kunnskap om vil det også være vanskelig å avgi et prognostisk utsagn om varighet av, og likedan om sykdommen er hovedårsak til reduksjonen av ervervsevnen. Denne erkjennelsen har den konsekvens at når årsaksforhold til uførepensjonering studeres, så vil starten på årsaken til uførepensjoneringen ligge langt foran i tid i forhold til virkningstidspunktet for uførepensjonen. Virkningstidspunktet settes i Norge, nesten uten unntak, til tre måneder før krav. Uføretidspunktet settes vanligvis til det tidspunktet man faller ut av arbeid, eller hvor ervervsevnen var så redusert at hvis vedkommende hadde hatt arbeidsmulighet, ville hun ikke vært i stand til å arbeide. Årsaksstudier som ikke tar tilstrekkelig hensyn til dette har derfor en iboende risiko for at man måler effekten av trygdeprosessen på eksponering like mye som motsatt.

Uførepensjon er sterkt assosiert med økende alder.
Forskning som ser på risikofaktorer for uførepensjonering vil derfor i stor grad være mest relevant for de eldste aldersgruppene. I tillegg til at unge uføre ofte har et annet sykdomspanorama enn eldre, har de en løsere tilknytning til arbeidslivet, og de har oftere mottatt sosialhjelp eller ledighetstrygd forut for uførepensjon (47). Det er derfor grunn til å tro at uførepensjonering hos unge har andre årsaker enn hos eldre. Kun et fătall av studiene vi har identifisert har sett spesielt på dette.

Mange studier blir motivert av at fagfolk ser helseskadelige forhold som kan føre til uførepensjonering. Vi ser av resultatene i tabell 2 at de fleste forhold som blir rapportert har statistisk signifikante effekter. Hvis slike studier ikke viser noen effekt, kan det føre til at studiene ikke blir publisert eller at resultatene faller ut av presentasjonen. Denne typen publiseringsbias kan være betydelig. Det er med andre ord viktig for videre forskning at også negative funn publiseres.

\section{KONKLUSJON}

Vi har en god del relevant kunnskap omkring årsaker til ervervsmessig uførhet i Norden, utviklet gjennom kvantitativ epidemiologisk - men også annen type forskning. Når vi likevel ikke greier å gjøre de sosiale eller økonomiske grep som reduserer utstøtingen fra arbeidslivet, kan det skyldes tunge trender og interessekonflikter som ikke uten videre påvirkes av forskningens dagsorden. Men mulighetene for å ta viktige grep kan fortsatt skyldes kunnskapsmangel, eller manglende implementering av den kunnskapen vi har i praksis. Dette viser at en løpende forskning omkring årsaker til sykefravær og ervervsmessig uførhet er viktig, da de politiske, sosiale, økonomiske og kulturelle forholdene i samfunnet er i endring. Politiske grep for å rette på problemer på ett samfunnsområde kan ha uønskede bivirkninger på et annet. Det er derfor viktig med fortløpende forskning på dette feltet med utgangspunkt i relevante teorier som både bidrar til analyse av situasjonen, setter viktige samfunnsforhold på dagsorden og utvikler ny kunnskap som er nødvendig for en positiv utvikling for deltakelse i arbeidslivet.

\section{REFERANSER}

1. Brage S. Trygdeordninger i Norden. Tidsskr Nor Lageforen 2002; 122: 1486.

2. OECD. The OECD "Sickness, Disability and Work" project. Paris 2009.

3. Nav. Arkiv - Uføreytelser samlet pr. 30. november 2008. Vol. 2009.

4. Bloch FS, Prins R. Who returns to work \& why?: a six-country study on work incapacity \& reintegration. New Brunswick, U.S.A.: Transaction Publishers 2001.

5. Nav. Statistikk pr. 30. juni 2009. Vol. 2009.

6. Westin S. Welfare for all - or only for the needy? Lancet 2008; 372: 1609-10.

7. Lundberg O, Yngwe MÅ, Stjärne MK, Elstad JI, Ferrarini T, Kangas O, et al. The role of welfare state principles and generosity in social policy programmes for public health: an international comparative study. Lancet 2008; 372: 1633-40.

8. Hansen H-T. Kunnskapsstatus for den nordiske trygdeforskningen på 1990-tallet. Bergen: Stiftelsen for samfunns- og næringslivforskning 1999.

9. SBU. Sjukskrivning - orsaker, konsekvenser och praxis Vol. 167. Stockholm: Statens beredning för medicinsk utvärdering - SBU 2003. 
10. Ose SO. Sykefravær: kunnskapsstatus og problemstillinger. Trondheim: SINTEF Helse 2006.

11. Krokstad S, Johnsen R, Westin S. Medisinske og ikke-medisinske risikofaktorer for uførepensjon. Tidsskr Nor Laegeforen 2002; 122: 1479-85.

12. Krokstad S, Johnsen R, Westin S. Social determinants of disability pension: A 10-year follow-up of 62000 people in a Norwegian county population. Int J Epidemiol 2002; 31: 1183-91.

13. Karlsson N, Borg K, Carstensen J, Hensing G, Alexanderson K. Risk of disability pension in relation to gender and age in a Swedish county; a 12-year population based, prospective cohort study. Work 2006; 27: 173-9.

14. Gjesdal S, Lie RT, Maeland JG. Variations in the risk of disability pension in Norway 1970-99. A genderspecific age-period-cohort analysis. Scand J Public Health 2004; 32: 340-8.

15. Otterblad Olausson P, Haglund B, Ringback Weitoft G, Cnattingius S. Teenage childbearing and long-term socioeconomic consequences: A case study in Sweden. Fam Plann Perspect 2001; 33: 70-4.

16. Gravseth HM, Bjerkedal T, Irgens LM, Aalen OO, Selmer R, Kristensen P. Life course determinants for early disability pension: A follow-up of Norwegian men and women born 1967-1976. Eur J Epidemiol 2007; 22: $533-43$.

17. Upmark M, Lundberg I, Sadigh J, Bigert C. Conditions during childhood and adolescence as explanations of social class differences in disability pension among young men. Scand J Public Health 2001; 29: 96-103.

18. Upmark M, Karlsson G, Romelsjo A. Drink driving and criminal behaviours as risk factors for receipt of disability pension and sick leave: A prospective study of young men. Addiction 1999; 94: 507-19.

19. Karnehed N, Rasmussen F, Kark M. Obesity in young adulthood and later disability pension: A populationbased cohort study of 366,929 Swedish men. Scand J Public Health 2007; 35: 48-54.

20. Visscher TLS, Rissanen A, Seidell JC, Heliovaara M, Knekt P, Reunanen A, et al. Obesity and unhealthy lifeyears in adult finns: An empirical approach. Arch Intern Med 2004; 164: 1413-20.

21. Mykletun A, Overland S, Dahl AA, Krokstad S, Bjerkeset O, Glozier N, et al. A population-based cohort study of the effect of common mental disorders on disability pension awards. Am J Psychiat 2006; 163: 1412-8.

22. Krokstad S, Magnus P, Skrondal A, Westin S. The importance of social characteristics of communities for the medically based disability pension. Eur J Public Health 2004; 14: 406-12.

23. Hannerz H, Tuchsen F, Spangenberg S, Albertsen K. Industrial differences in disability retirement rates in Denmark, 1996-2000. Int J Occup Med Environ Health 2004; 17: 465-71.

24. Karpansalo M, Manninen P, Lakka TA, Kauhanen J, Rauramaa R, Salonen JT, et al. Physical workload and risk of early retirement: prospective population-based study among middle-aged men. J Occup Environ Med 2002; 44: 930-9.

25. Vahtera J, Kivimaki M, Forma P, Wikstrom J, Halmeenmaki T, Linna A, et al. Organisational downsizing as a predictor of disability pension: The 10-town prospective cohort study. J Epidemiol Community Health 2005; 59: $238-42$.

26. Lund T, Kivimaki M, Labriola M, Villadsen E, Christensen KB. Using administrative sickness absence data as a marker of future disability pension: The prospective DREAM study of Danish private sector employees. Occup Environ Med 2008; 65: 28-31.

27. Gjesdal S, Ringdal PR, Haug K, Maeland JG. Predictors of disability pension in long-term sickness absence: results from a population-based and prospective study in Norway 1994-1999. Eur J Public Health 2004; 14: 398-405.

28. Karlsson NE, Carstensen JM, Gjesdal S, Alexanderson KA, Karlsson NE, Carstensen JM, et al. Risk factors for disability pension in a population-based cohort of men and women on long-term sick leave in Sweden. Eur J Public Health 2008; 18: 224-31.

29. Bratberg E, Gjesdal S, Maeland JG. Sickness absence with psychiatric diagnoses: individual and contextual predictors of permanent disability. Health and Place 2009; 15: 308-14.

30. Gjesdal S, Maeland JG, Hagberg J, Alexanderson K. Socioeconomic inequalities and mortality among disability pensioners in Norway - A population-based cohort study. Norsk Epidemiologi 2007; 17: 29-35.

31. Karlsson NE, Carstensen JM, Gjesdal S, Alexanderson KA. Mortality in relation to disability pension: findings from a 12-year prospective population-based cohort study in Sweden. Scand J Public Health 2007; 35: 341-7.

32. Eden L, Andersson IH, Ejlertsson G, Ekstrom BI, Johansson Y, Leden I, et al. Return to work still possible after several years as a disability pensioner due to musculoskeletal disorders: A population-based study after new legislation in Sweden permitting "Resting disability pension". Work 2006; 26: 147-55.

33. Ydreborg B, Ekberg K, Nordlund A. Health, quality of life, social network and use of health care: A comparison between those granted and those not granted disability pensions. Disabil Rehabil 2006; 28: 25-32.

34. Ydreborg BA, Ekberg K. Disqualified for disability pension - a case/referent study. Disabil Rehabil 2004; 26: 1079-86.

35. Eden L, Ejlertsson G, Leden I. Health and health care utilization among early retirement pensioners with musculoskeletal disorders. Scand J Prim Health Care 1995; 13: 211-6.

36. Eden L, Ejlertsson G, Petersson J. Quality of life among early retirees. Exp Aging Res 1999; 25: 471-5.

37. Dellve L, Lagerstrom M, Hagberg M. Work-system risk factors for permanent work disability among homecare workers: A case-control study. Int Arch Occ Env Health 2003; 76: 216-24. 
38. Medin J, Nordlund A, Ekberg K. Sick leave, disability pension and health-care-seeking behaviour prior to stroke, among people aged 30-65: A case-control study. Brain Injury 2007; 21: 457-63.

39. Ringdal PR, Haug K, Maeland JG. Fører systematisk vurdering av Sykmelding II-erklæringer til lavere trygdeforbruk? Tidsskr Nor Lageforen 2002; 122: 157-60.

40. Goine H, Knutsson A, Marklund S, Karlsson B. Sickness absence and early retirement at two workplaces Effects of organisational intervention in Sweden. Soc Sci Med 2004; 58: 99-108.

41. Aronowitz RA. Making sense of illness: science, society, and disease. Cambridge: Cambridge University Press 1998.

42. Rognerud M, Strand BH, Næss Ø. Sosial ulikhet i helse: en faktarapport. Oslo: Folkehelseinstituttet 2007.

43. Albertsen K, Lund T, Christensen KB, Kristensen TS, Villadsen E, Albertsen K, et al. Predictors of disability pension over a 10-year period for men and women. Scand J Public Health 2007; 35: 78-85.

44. Stattin M, Jarvholm B. Occupation, work environment, and disability pension: A prospective study of construction workers. Scand J Public Health 2005; 33: 84-90.

45. Westin S, Schlesselman JJ, Korper M. Long-term effects of a factory closure: Unemployment and disability during ten years' follow-up. J Clin Epidemiol 1989; 42: 435-41.

46. Rege M, Telle K, Votruba M. The effect of plant downsizing on disability pension utilization. Oslo: Statistics Norway 2005.

47. Fevang E, Røed K. Veien til uføretrygd i Norge. Oslo: Frischsenteret 2006.

48. Rege M, Telle K, Votruba M. Social interaction effects in disability pension participation: evidence from plant downsizing. Oslo: Statistics Norway 2007.

49. Krokstad S, Westin S. Disability in society-medical and non-medical determinants for disability pension in a Norwegian total county population study. Soc Sci Med 2004; 58: 1837-48.

50. Sivertsen B, Overland S, Neckelmann D, Glozier N, Krokstad S, Pallesen S, et al. The long-term effect of insomnia on work disability: The HUNT-2 historical cohort study. Am J Epidemiol 2006; 163: 1018-24.

51. Harkonmaki K, Silventoinen K, Levalahti E, Pitkaniemi J, Huunan-Seppala A, Klaukka T, et al. The genetic liability to disability retirement: A 30-year follow-up study of 24,000 finnish twins. PLoS ONE 2008; 3 (10).

\section{Appendiks 1-A}

1 Albertsen K, Lund T, Christensen KB, Kristensen TS, Villadsen E, Albertsen K, et al. Predictors of disability pension over a 10-year period for men and women. Scand J Public Health. 2007; 35: 78-85.

2 Appelberg K, Romanov K, Heikkila K, Honkasalo ML, Koskenvuo M. Interpersonal conflict as a predictor of work disability: A follow-up study of 15,348 Finnish employees. $J$ Psychosom Res. 1996; 40: 157-67.

3 Biering-Sorensen F, Lund J, Hoydalsmo OJ, Darre EM, Deis A, Kryger P, et al. Risk indicators of disability pension. A 15 year follow-up study. Dan Med Bull. 1999; 46: 258-62.

4 Brun C, Boggild H, Eshoj P. Socio-economic risk indicators for disability pension within the Danish workforce: A register based cohort study from 1994 to 1998. [Danish]. Ugeskrift for Laeger. 2003; 165: 3315-9.

5 Bultmann U, Christensen KB, Burr H, Lund T, Rugulies R. Severe depressive symptoms as predictor of disability pension: A 10-year follow-up study in Denmark. Eur J Public Health. 2008; 18: 232-4.

6 Carlsen K, Oksbjerg Dalton S, Frederiksen K, Diderichsen F, Johansen $\mathrm{C}$, Carlsen $\mathrm{K}$, et al. Cancer and the risk for taking early retirement pension: a Danish cohort study. Scand $J$ Public Health. 2008; 36: 117-25.

7 Christensen KB, Feveile H, Labriola M, Lund T. The impact of psychosocial work environment factors on the risk of disability pension in Denmark. Eur J Public Health. 2008; 18: 235-7.

8 Friis K, Ekholm O, Hundrup YA, Friis K, Ekholm O, Hundrup YA. The relationship between lifestyle, working environment, socio-demographic factors and expulsion from the labour market due to disability pension among nurses. Scand $J$ Caring Sci. 2008; 22: 241-8.

9 Gamperiene M, Nygard JF, Brage S, Bjerkedal T, Bruusgaard $\mathrm{D}$, Gamperiene $\mathrm{M}$, et al. Duration of employment is not a pre- dictor of disability of cleaners: a longitudinal study. Scand $J$ Public Health. 2003; 31: 63-8.

10 Gjesdal S, Lie RT, Maeland JG. Variations in the risk of disability pension in Norway 1970-99. A gender-specific ageperiod-cohort analysis. Scand J Public Health 2004; 32: 340-8.

11 Gravseth HM, Bjerkedal T, Irgens LM, Aalen OO, Selmer R, Kristensen P. Life course determinants for early disability pension: A follow-up of Norwegian men and women born 1967-1976. Eur J Epidemiol. 2007; 22: 533-43.

12 Gravseth HM, Bjerkedal T, Irgens LM, Aalen OO, Selmer R, Kristensen P. Influence of physical, mental and intellectual development on disability in young Norwegian men. Eur $J$ Public Health. 2008; 18: 650-5.

13 Husemoen LL, Osler M, Godtfredsen NS, Prescott E, Husemoen LLN, Osler M, et al. Smoking and subsequent risk of early retirement due to permanent disability. Eur J Public Health. 2004; 14: 86-92.

14 Kaprio J, Sarna S, Fogelholm M, Koskenvuo M. Total and occupationally active life expectancies in relation to social class and marital status in men classified as healthy at 20 in Finland. J Epidemiol Community Health. 1996; 50: 653-60.

15 Kark M, Karnehed N, Rasmussen F. Blood pressure in young adulthood and later disability pension. A population-based study on 86672 men from Sweden. Blood Pressure. 2007; 16: 362-6.

16 Karlsson N, Borg K, Carstensen J, Hensing G, Alexanderson $\mathrm{K}$. Risk of disability pension in relation to gender and age in a Swedish county; a 12-year population based, prospective cohort study. Work. 2006; 27: 173-9.

17 Karnehed N, Rasmussen F, Kark M. Obesity in young adulthood and later disability pension: A population-based cohort study of 366,929 Swedish men. Scand J Public Health. 2007; 35: 48-54.

18 Karpansalo M, Manninen P, Lakka TA, Kauhanen J, Rauramaa R, Salonen JT, et al. Physical workload and risk of early 
retirement: prospective population-based study among middleaged men. J Occup Environ Med. 2002; 44: 930-9.

19 Karpansalo M, Lakka TA, Manninen P, Kauhanen J, Rauramaa R, Salonen JT. Cardiorespiratory fitness and risk of disability pension: A prospective population based study in Finnish men. Occup Environ Med. 2003; 60: 765-9.

20 Karpansalo M, Manninen P, Kauhanen J, Lakka TA, Salonen JT. Perceived health as a predictor of early retirement. Scand $J$ Work Env Hea. 2004; 30: 287-92.

21 Karpansalo M, Kauhanen J, Lakka TA, Manninen P, Kaplan GA, Salonen JT. Depression and early retirement: prospective population based study in middle aged men. J Epidemiol Community Health. 2005; 59: 70-4.

22 Kivimaki M, Forma P, Wikstrom J, Halmeenmaki T, Pentii J, Elovainio M, et al. Sickness absence as a risk marker of future disability pension: The 10-town study. $J$ Epidemiol Community Health. 2004; 58: 710-1.

23 Kivimaki M, Ferrie JE, Hagberg J, Head J, Westerlund H, Vahtera J, et al. Diagnosis-specific sick leave as a risk marker for disability pension in a Swedish population. $J$ Epidemiol Community Health. 2007; 61: 915-20.

24 Koivumaa-Honkanen H, Koskenvou M, Honkanen RJ, Viinamaki H, Heikkila K, Kaprio J. Life dissatisfaction and subsequent work disability in an 11-year follow-up. Psychol Med. 2004; 34: 221-8.

25 Krokstad S, Johnsen R, Westin S. Medisinske og ikkemedisinske risikofaktorer for uførepensjon. Tidsskr Nor Laegeforen. 2002; 122: 1479-85.

26 Krokstad S, Johnsen R, Westin S. Social determinants of disability pension: A 10 -year follow-up of 62000 people in a Norwegian county population. Int J Epidemiol. 2002; 31: 1183-91.

27 Krokstad S, Magnus P, Skrondal A, Westin S. The importance of social characteristics of communities for the medically based disability pension. Eur J Public Health 2004; 14: 406-12.

28 Labriola M, Lund T. Self-reported sickness absence as a risk marker of future disability pension. Prospective findings from the DWECS/DREAM study 1990-2004. Int J Med Sci. 2007; 4: $153-8$.

29 Lund T, Csonka A. Risk Factors in Health, Work Environment, Smoking Status, and Organizational Context for Work Disability. Am J Ind Med. 2003; 44: 492-501.

30 Manninen P, Heliovaara M, Riihimaki H, Makela P. Does psychological distress predict disability? Int $J$ Epidemiol. 1997; 26: 1063-70.

31 Moster D, Lie RT, Markestad T. Long-term medical and social consequences of preterm birth. New Engl J Med. 2008; 359: 262-73.

32 Mykletun A, Overland S, Dahl AA, Krokstad S, Bjerkeset O, Glozier N, et al. A population-based cohort study of the effect of common mental disorders on disability pension awards. $\mathrm{Am}$ $J$ Psychiat. 2006; 163: 1412-8

33 Mansson NO, Eriksson KF, Israelsson B, Ranstam J, Melander A, Rastam L. Body mass index and disability pension in middle-aged men - non-linear relations. Int J Epidemiol. 1996; 25: $80-5$.

34 Mansson NO, Rastam L, Eriksson KF, Israelsson B. Alcohol consumption and disability pension among middle-aged men. Ann Epidemiol. 1999; 9: 341-8.

35 Mansson NO, Rastam L. Self-rated health as a predictor of disability pension and death - a prospective study of middleaged men. Scand J Public Health. 2001; 29: 151-8.

36 Mansson NO, Rastam L, Eriksson KF, Israelsson B. Socioeconomic inequalities and disability pension in middle-aged men. Int J Epidemiol. 1998; 27: 1019-25.

37 Mansson NO, Merlo J. The relation between self-rated health, socioeconomic status, body mass index and disability pension among middle-aged men. Eur J Epidemiol. 2001; 17: 65-9.

38 Otterblad Olausson P, Haglund B, Ringback Weitoft G, Cnattingius $\mathrm{S}$. Teenage childbearing and long-term socioeconomic consequences: A case study in Sweden. Fam Plann Perspect. 2001; 33: 70-4.

39 Overland S, Glozier N, Sivertsen B, Stewart R, Neckelmann $\mathrm{D}$, Krokstad S, et al. A comparison of insomnia and depression as predictors of disability pension: The HUNT study. Sleep. 2008; 31: 875-80.

40 Rissanen A, Heliovaara M, Knekt P, Reunanen A, Aromaa A, Maatela J. Risk of disability and mortality due to overweight in a Finnish population. BMJ. 1990; 301: 835-7.

41 Rissanen A, Heliovaara M, Alaranta H, Taimela S, Malkia E, Knekt $\mathrm{P}$, et al. Does good trunk extensor performance protect against back-related work disability? J Rehabil Med. 2002; 34: $62-6$.

42 Sivertsen B, Overland S, Neckelmann D, Glozier N, Krokstad $\mathrm{S}$, Pallesen S, et al. The long-term effect of insomnia on work disability: The HUNT-2 historical cohort study. Am J Epidemiol. 2006; 163: 1018-24.

43 Sivertsen B, Overland S, Glozier N, Bjorvatn B, Maeland JG, Mykletun A. The effect of OSAS on sick leave and work disability. Eur Respir J. 2008; 32: 1497-503.

44 Stattin M, Jarvholm B. Occupation, work environment, and disability pension: A prospective study of construction workers. Scand J Public Health. 2005; 33: 84-90.

45 Suominen S, Gould R, Ahvenainen J, Vahtera J, Uutela A, Koskenvuo M. Sense of coherence and disability pensions. A nationwide, register based prospective population study of 2196 adult Finns. J Epidemiol Community Health. 2005; 59: 455-9.

46 Suoyrjo H, Hinkka K, Kivimaki M, Klaukka T, Pentti J, Vahtera J. Allocation of rehabilitation measures provided by the Social Insurance Institution in Finland: A register linkage study. J Rehabil Med. 2007; 39: 198-204.

47 Tuchsen F, Christensen KB, Lund T, Feveile H. A 15-year prospective study of shift work and disability pension. Occup Environ Med. 2008; 65: 283-5.

48 Upmark M, Moller J, Romelsjo A. Longitudinal, populationbased study of self reported alcohol habits, high levels of sickness absence, and disability pensions. $J$ Epidemiol Community Health. 1999; 53: 223-9.

49 Upmark M, Lundberg I, Sadigh J, Bigert C. Conditions during childhood and adolescence as explanations of social class differences in disability pension among young men. Scand $J$ Public Health. 2001; 29: 96-103.

50 Vahtera J, Kivimaki M, Forma P, Wikstrom J, Halmeenmaki T, Linna A, et al. Organisational downsizing as a predictor of disability pension: The 10-town prospective cohort study. $J$ Epidemiol Community Health. 2005; 59: 238-42.

51 Visscher TLS, Rissanen A, Seidell JC, Heliovaara M, Knekt P, Reunanen A, et al. Obesity and unhealthy life-years in adult finns: An empirical approach. Arch Intern Med. 2004; 164: 1413-20.

\section{Appendiks 1-B}

1 Bjerkedal T, Kristensen P, Skjeret GA, Brevik JI, Bjerkedal T, Kristensen $\mathrm{P}$, et al. Oppfølging av personer som fikk grunnstønad og/eller hjelpestønad som barn. Tidsskr Nor Laegeforen 2006; 126: 436-9.

2 Bjerkedal T, Thune O, Irgens LM. Tidlig identifisering av barn med økt risiko for varig arbeidsuførhet. Tidsskr Nor Lageforen 1999; 119: 652-6.

3 Hagen KB, Tambs K, Bjerkedal T. A prospective cohort study of risk factors for disability retirement because of back pain in the general working population. Spine. 2002; 27: 1790-6.

4 Hagen KB, Tambs K, Bjerkedal T. What mediates the inverse association between education and occupational disability from back pain?-A prospective cohort study from the NordTrondelag health study in Norway. Soc Sci Med. 2006; 63: 1267-75. 
5 Hannerz H, Tuchsen F, Spangenberg S, Albertsen K. Industrial differences in disability retirement rates in Denmark, 19962000. Int J Occup Med Environ Health. 2004; 17: 465-71.

6 Harkonmaki K, Silventoinen K, Levalahti E, Pitkaniemi J, Huunan-Seppala A, Klaukka T, et al. The genetic liability to disability retirement: A 30-year follow-up study of 24,000 finnish twins. PLOS ONE. 2008; 3(10).

7 Holmberg SA, Thelin AG, Holmberg SAC, Thelin AG. Primary care consultation, hospital admission, sick leave and disability pension owing to neck and low back pain: a 12-year prospective cohort study in a rural population. $B M C$ Musculoskelet Disord. 2006; 7: 66.

8 Holte HH, Tambs K, Bjerkedal T. Manual work as predictor for disability pensioning with osteoarthritis among the employed in Norway 1971-1990. Int J Epidemiol. 2000; 29: 487-94.

9 Koskela RS, Klockars M, Jarvinen E. Mortality and disability among cotton mill workers. Brit J Ind Med. 1990; 47: 384-91.

10 Kristensen P, Bjerkedal T. Trender i deltakelse i arbeidslivet betydningen av kronisk sykdom som barn og utdanningsnivå. Tidsskr Nor Laegeforen. 2004; 124: 2879-83.

11 Mansson NO, Merlo J, Ostergren PO. Is there an interaction between self-rated health and medication with analgesics and hypnotics in the prediction of disability pension? Scand $J$ Public Health. 2002; 30: 267-73.

12 Riise T, Knut Rasmus K, Moen B. A cohort study of disability pensioning among Norwegian painters, construction workers, and workers in food processing. Epidemiology. 1995; 6: 132-6.

13 Riise T, Moen BE, Kyvik KR, Riise T, Moen BE, Kyvik KR. Organic solvents and the risk of multiple sclerosis.[see comment]. Epidemiology. 2002; 13: 718-20.

14 Upmark M, Karlsson G, Romelsjo A. Drink driving and criminal behaviours as risk factors for receipt of disability pension and sick leave: A prospective study of young men. Addiction. 1999; 94: 507-19.

15 Upmark M, Lundberg I, Sadigh J, Allebeck P, Bigert C. Psychosocial characteristics in young men as predictors of early disability pension with a psychiatric diagnosis. Soc Psych Epid. 1999; 34: 533-40.

16 Virtanen M, Kivimaki M, Vahtera J, Elovainio M, Sund R, Virtanen P, et al. Sickness absence as a risk factor for job termination, unemployment, and disability pension among temporary and permanent employees.[see comment]. Occup Environ Med. 2006; 63: 212-7.

\section{Appendiks 2}

1 Ahlgren A, Broman L, Bergroth A, Ekholm J, Ahlgren A, Broman L, et al. Disability pension despite vocational rehabilitation? A study from six social insurance offices of a county. Int J Rehabil Res. 2005; 28: 33-42.

2 Alexanderson KA, Borg KE, Hensing GK, Alexanderson KAE, Borg KE, Hensing GKE. Sickness absence with lowback, shoulder, or neck diagnoses: an 11-year follow-up regarding gender differences in sickness absence and disability pension. Work. 2005; 25: 115-24.

3 Andersen MM, Permin H, Albrecht F. Illness and disability in Danish Chronic Fatigue Syndrome patients at diagnosis and 5year follow-up. J Psychosom Res. 2004; 56: 217-29.

4 Andren D. Long-term absenteeism due to sickness in Sweden. How long does it take and what happens after? Eur J Health Econ. 2007; 8: 41-50.

5 Becker N, Hojsted J, Sjogren P, Eriksen J. Sociodemographic predictors of treatment outcome in chronic non-malignant pain patients. Do patients receiving or applying for disability pension benefit from multidisciplinary pain treatment? Pain. 1998; 77: 279-87.

6 Bergh H, Baigi A, Mansson J, Mattsson B, Marklund B, Bergh $\mathrm{H}$, et al. Predictive factors for long-term sick leave and disability pension among frequent and normal attenders in primary health care over 5 years. Public Health. 2007; 121: 25-33.

7 Borg K, Hensing G, Alexanderson K. Predictive factors for disability pension - an 11-year follow up of young persons on sick leave due to neck, shoulder, or back diagnoses. Scand $J$ Public Health. 2001; 29: 104-12.

8 Borg K, Hensing G, Alexanderson K, Borg K, Hensing G, Alexanderson K. Risk factors for disability pension over 11 years in a cohort of young persons initially sick-listed with low back, neck, or shoulder diagnoses. Scand J Public Health. 2004; 32: 272-8.

9 Bratberg E, Gjesdal S, Maeland JG. Sickness absence with psychiatric diagnoses: individual and contextual predictors of permanent disability. Health and Place. 2009; 15: 308-14.

10 Chung CP, Sokka T, Arbogast PG, Pincus T. Work disability in early rheumatoid arthritis: Higher rates but better clinical status in Finland compared with the US. Ann Rheum Dis. 2006; 65: 1653-7.

11 Gjesdal S, Bratberg E. The role of gender in long-term sickness absence and transition to permanent disability benefits: Results from a multiregister based, prospective study in Norway 1990-1995. Eur J Public Health. 2002; 12: 180-6.

12 Gjesdal S, Bratberg E. Diagnosis and duration of sickness absence as predictors for disability pension: Results from a three-year, multi-register based* and prospective study. Scand $J$ Public Health. 2003; 31: 246-54.

13 Gjesdal S, Haug K, Ringdal PR, Vollset SE, Maeland JG. Risiko for uførepensjonering blant unge langtidssykemeldte. Tidsskr Nor Laegeforen. 2005; 125: 1801-5.

14 Gjesdal S, Ringdal PR, Haug K, Maeland JG. Predictors of disability pension in long-term sickness absence: results from a population-based and prospective study in Norway 19941999. Eur J Public Health. 2004; 14: 398-405.

15 Gjesdal S, Ringdal PR, Haug K, Maeland JG. Long-term sickness absence and disability pension with psychiatric diagnoses: A population-based cohort study. Nord J Psychiat. 2008; 62: 294-301.

16 Hamalainen H, Maki J, Virta L, Keskimaki I, Mahonen M, Moltchanov V, et al. Return to work after first myocardial infarction in 1991-1996 in Finland. Eur J Public Health. 2004; 14: $350-3$.

17 Harkapaa K. Psychosocial factors as predictors for early retirement in patients with chronic low back pain. $J$ Psychosom Res. 1992; 36: 553-9.

18 Jantti J, Aho K, Kaarela K, Kautiainen H. Work disability in an inception cohort of patients with seropositive rheumatoid arthritis: A 20 year study. Rheumatology. 1999; 38: 1138-41.

19 Kaiser PO, Mattsson B, Marklund S, Wimo A. Health and disability pension - An intersection of disease, psychosocial stress and gender. Long term follow up of persons with impairment of the loco motor system. Work. 2008; 31: 209-19.

20 Karlsson NE, Carstensen JM, Gjesdal S, Alexanderson KA, Karlsson NE, Carstensen JM, et al. Risk factors for disability pension in a population-based cohort of men and women on long-term sick leave in Sweden. Eur J Public Health. 2008; 18: $224-31$.

21 Kjelsberg E, Dahl AA. High delinquency, disability and mortality - A register study of former adolescent psychiatric in-patients. Acta Psychiatr Scand. 1998; 98: 34-40.

22 Lund T, Kivimaki M, Labriola M, Villadsen E, Christensen $\mathrm{KB}$. Using administrative sickness absence data as a marker of future disability pension: The prospective DREAM study of Danish private sector employees. Occup Environ Med. 2008; 65: 28-31.

23 Pelkonen M, Marttunen M, Pulkkinen E, Laippala P, Lonnqvist J, Aro H. Disability pensions in severely disturbed inpatient adolescents. Twenty-year prospective study.[see comment]. Br J Psychiatry. 1998; 172: 159-63.

24 Peuckmann V, Ekholm O, Sjogren P, Rasmussen NK, Christiansen P, Moller S, et al. Health care utilisation and 
characteristics of long-term breast cancer survivors: Nationwide survey in Denmark. Eur J Cancer. 2009; 45: 625-33.

25 Puolakka K, Kautiainen H, Mottonen T, Hannonen P, Pohjolainen T, Korpela M, et al. Cost of Finnish statutory inpatient rehabilitation and its impact on functional and work capacity of patients with early rheumatoid arthritis: Experience from the FIN-RACo trial. Scand J Rheumatol. 2007; 36: 270-7.

26 Rytsala HJ, Melartin TK, Leskela US, Sokero TP, LestelaMielonen PS, Isometsa ET. Predictors of long-term work disability in Major Depressive Disorder: a prospective study. Acta Psychiatr Scand. 2007; 115: 206-13.

27 Rasanen P, Hakko H, Jokelainen J, Tiihonen J. Outcome of different types of long-term antidepressant treatments: A 3year follow-up study of 14,182 patients. $J$ Affect Dis. 1999; 55: 67-71.

28 Schalen W, Nordstrom G, Nordstrom CH. Economic aspects of capacity for work after severe traumatic brain lesions. Brain Injury. 1994; 8: 37-47.

29 Vaez M, Rylander G, Nygren A, Asberg M, Alexanderson K. Sickness absence and disability pension in a cohort of employees initially on long-term sick leave due to psychiatric disorders in Sweden. Soc Psych Epid. 2007; 42: 381-8.

\section{Appendiks 3}

1 Gjesdal S, Maeland JG, Hagberg J, Alexanderson K. Socioeconomic inequalities and mortality among disability pensioners in Norway - A population-based cohort study. Norsk Epidemiologi. 2007; 17: 29-35.

2 Gjesdal S, Maeland JG, Svedberg P, Hagberg J, Alexanderson $\mathrm{K}$. Role of diagnoses and socioeconomic status in mortality among disability pensioners in Norway - a population-based cohort study. Scand J Work Env Health 2008; 34: 479-82.

3 Karlsson NE, Carstensen JM, Gjesdal S, Alexanderson KA. Mortality in relation to disability pension: findings from a 12year prospective population-based cohort study in Sweden. Scand J Public Health. 2007; 35: 341-7.

4 Quaade T, Engholm G, Johansen AM, Moller H, Quaade T, Engholm G, et al. Mortality in relation to early retirement in Denmark: a population-based study. Scand J Public Health. 2002; 30: 216-22.

5 Wallman T, Wedel H, Johansson S, Rosengren A, Eriksson H, Welin L, et al. The prognosis for individuals on disability retirement An 18-year mortality follow-up study of 6887 men and women sampled from the general population. BMC Public Health. 2006; 6.

6 Wigers SH. Fibromyalgia outcome: the predictive values of symptom duration, physical activity, disability pension, and critical life events - a 4.5 year prospective study. J Psychosom Res. 1996; 41: 235-43.

\section{Appendiks 4}

1 Dellve L, Lagerstrom M, Hagberg M. Work-system risk factors for permanent work disability among home-care workers: A case-control study. Int Arch Occ Env Hea. 2003; 76: 216-24.

2 Eden L, Ejlertsson G, Leden I. Health and health care utilization among early retirement pensioners with musculoskeletal disorders. Scand J Prim Health Care. 1995; 13: 211-6.
3 Eden L, Ejlertsson G, Petersson J. Quality of life among early retirees. Exp Aging Res. 1999; 25: 471-5.

4 Eden L, Andersson IH, Ejlertsson G, Ekstrom BI, Johansson Y, Leden I, et al. Return to work still possible after several years as a disability pensioner due to musculoskeletal disorders: A population-based study after new legislation in Sweden permitting "Resting disability pension". Work. 2006; 26: $147-55$.

5 Medin J, Nordlund A, Ekberg K. Sick leave, disability pension and health-care-seeking behaviour prior to stroke, among people aged 30-65: A case-control study. Brain Injury. 2007; 21: 457-63.

6 Ydreborg BA, Ekberg K. Disqualified for disability pension a case/referent study. Disabil Rehabil. 2004; 26: 1079-86.

7 Ydreborg B, Ekberg K, Nordlund A. Health, quality of life, social network and use of health care: A comparison between those granted and those not granted disability pensions. Disabil Rehabil. 2006; 28: 25-32.

\section{Appendiks 5}

1 Goine H, Knutsson A, Marklund S, Karlsson B. Sickness absence and early retirement at two workplaces - Effects of organisational intervention in Sweden. Soc Sci Med. 2004; 58: 99-108.

2 Haugli L, Steen E, Laerum E, Nygard R, Finset A. Learning to have less pain - is it possible? A one-year follow-up study of the effects of a personal construct group learning programme on patients with chronic musculoskeletal pain. Patient Educ Couns. 2001; 45: 111-8.

3 Narbro K, Agren G, Jonsson E, Larsson B, Naslund I, Wedel $\mathrm{H}$, et al. Sick leave and disability pension before and after treatment for obesity: A report from the Swedish Obese Subjects (SOS) study. Int J Obesity. 1999; 23: 619-24.

4 Pihlajamaki H, Myllynen P, Bostman O. Return to work after posterolateral fusion with transpedicular instrumentation for spondylarthrosis of the lumbosacral spine. Ann Chir Gynaecol. 1996; 85: 63-6.

5 Puolakka K, Kautiainen H, Mottonen T, Hannonen P, Hakala M, Korpela M, et al. Predictors of productivity loss in early rheumatoid arthritis: a 5 year follow up study. Ann Rheum Dis. 2005; 64: 130-3.

6 Puolakka K, Kautiainen H, Mottonen T, Hannonen P, Pohjolainen T, Korpela M, et al. Cost of Finnish statutory inpatient rehabilitation and its impact on functional and work capacity of patients with early rheumatoid arthritis: Experience from the FIN-RACo trial. Scand J Rheumatol. 2007; 36: 270-7.

7 Ringdal PR, Haug K, Maeland JG. Fører systematisk vurdering av Sykmelding II-erklæringer til lavere trygdeforbruk? Tidsskr Nor Laegeforen. 2002; 122: 157-60.

8 Suoyrjo H, Oksanen T, Hinkka K, Pentti J, Kivimaki M, Klaukka $\mathrm{T}$, et al. A comparison of two multidisciplinary inpatient rehabilitation programmes for fibromyalgia: A register linkage study on work disability. J Rehabil Med. 2009; 41: 66-72.

9 Puolakka K, Kautiainen H, Mottonen T, Hannonen P, Korpela $\mathrm{M}$, Julkunen $\mathrm{H}$, et al. Impact of Initial Aggressive Drug Treatment with a Combination of Disease-Modifying Antirheumatic Drugs on the Development of Work Disability in Early Rheumatoid Arthritis: A Five-Year Randomized Followup Trial. Arthritis Rheum. 2004; 50: 55-62. 